\title{
A social work study on job placement and dropout
}

\author{
Mohammad Reza Iravani ${ }^{* a}$ and Zeynab Razi ${ }^{b}$
}

${ }^{a}$ Department of Social Work, Islamic Azad University of Khomeinishahr, Khomeinishahr Branch, Daneshjou Blvd, Iran ${ }^{b}$ Department of Sociology, Islamic Azad University, Jahrom Branch, Iran

\begin{tabular}{l}
\hline A R T I C L E I N F O \\
\hline Article history: \\
Received July 10, 2011 \\
Received in Revised form \\
October, 3, 2011 \\
Accepted 10 October 2011 \\
Available online \\
14 October 2011 \\
\hline Keywords: \\
Job opportunity \\
People quality of life \\
Education \\
Women
\end{tabular}

\section{A B S T R A C T}

\begin{abstract}
For many decades, women were discriminated against men for paying less in equal job positions. Most high-level positions were assigned among men and women were considered in lower social position. However, during the past few decades, there have been tremendous efforts to provide equal job opportunity among people with different gender and race in various countries. The proposed study of this paper attempt to investigate women's position in terms of two aspects of economic and education for the people who live in a city of Esfahan, Iran. We design a questionnaire and distribute among 880 people who are randomly chosen from a population of 441782 residence. The result of our survey confirms that Iranian women are placed well and job placement of the Iranian women is low. The second part of our survey concludes that Iranian women were quite forward and there will be definite reasons for drop out.
\end{abstract}

(c) 2012 Growing Science Ltd. All rights reserved.

\section{Introduction}

For decades, women were discriminated against men for paying less in equal job positions. Most high-level job positions were assigned among men, and women were considered in lower social position. However, during the past few decades, there have been tremendous efforts to provide equal job opportunities among people with different genders and races (Wild, 1970). Nevertheless, men are believed to be the primary source of family income in most places and there are still many differences between two equal jobs between men and women. Women may find it easier to look for some jobs in the event of economic crises. There are many studies for deregulating job placement in the world. The selection of a job depends on various factors such as various factors such as place, job title. Boschmann (2011) investigated job access, location decision, and the working poor in a qualitative study in the Columbus, Ohio metropolitan area.

Burrell et al. (1997) presented equal job opportunities for women employees in the hospitality industry by comparing data different countries of France, Italy, Spain and the UK. Winterhager et al.

\footnotetext{
* Corresponding author. Tel: + 989130758065

E-mail addresses: iravani@iaukhsh.ac.ir (M. R. Iravani)

(C) 2012 Growing Science Ltd. All rights reserved 
(2006) presented a micro-econometric evaluation of an innovative voucher scheme in Germany. They explain that job placement vouchers could be stated as a way to spur competition between public and private job placement activities. The German government launched this tool to end the public placement monopoly and to subsidize its private competitors. They examined very rich administrative data from the federal employment agency and used propensity score matching as a method to solve the basic evaluation problem and to provide the effect of the vouchers. They reported positive treatment effects on the employment probability after one year of 6.5 percentage points in Western Germany and presented a measure for deadweight loss.

Pfister and Radtke (2006) investigated the reasons for dropping out among female and male leaders in German sports federations. They reported variety of leadership biographies and issues to leave the sport associations, which had to do mostly with the culture of the organization. However, they found some patterns and typical processes as well as different types of dropout. Gender differences appeared especially with regard to attitudes towards dealing with power, prestige and conflicts. According to their results, the women not only experienced sex-specific discriminations but also showed a much higher emotional involvement in conflicts and the drop-out-processes as a whole.

Kriesi et al. (2010) investigated in job opportunities for men and women in the Swiss labor market 1962-1989. They explained job opportunities for salient groups of labor-market participants and their ranking within the labor queues based on separate regression analyses for men and women. Their findings were different in terms of gender and indicated that macro-level processes, such as the economic cycle, play an important role for men's job opportunities. They also specified that job opportunities strongly depend on occupational credentials whereas educational attainment is a minor part.

Chi (1999) presented a study on job placement for handicapped workers using job analysis data. Hurd and Panis (2006) examined the choice to cash out pension rights at change or retirement. Raymo and Lim (2011) studied educational changes in married women's labor force attachment in Japan using 10 waves of information from a nationally representative survey. They concluded that university graduates are both more likely to remain in and less likely to reenter the labor force relative to women with a high school education or less. Their relatively low likelihood of labor force exit reflects educational changes in occupational characteristics, especially employment in full-time and standard jobs. However, junior college and university graduates remain substantially less likely to reenter the labor force net of family circumstances, characteristics of previous employment, and efforts to control for unobserved characteristics. They concluded with speculation about the implications of these educational differences in married women's employment for stratification.

Sabharwal (2011) studied job satisfaction patterns of scientists and engineers by status of birth. They investigated job satisfaction of foreign-born scientists and engineers in academia and compared them with US-born and reported that despite higher research productivity, foreign-born are less satisfied than their native-born peers.

The present study of this paper investigates the job placement and dropout among women who live in one the biggest provinces of Iran, Esfahan. The proposed study of this paper first presents details of our survey in section 2 and section 3 provides the results of our investigation. Finally, concluding remarks are given in the last to summarize the contribution of this paper.

\section{The proposed study}

According to the official census held in 2006, there are 5026 people residing in this city including 2575 men and 2451 women. We have used the following formula to calculate the minimum number of sample size, 
$n=\frac{N \times z_{\alpha / 2}^{2} \times p \times q}{\varepsilon^{2} \times(N-1)+z_{\alpha / 2}^{2} \times p \times q}$,

where $N$ is the population size, $p=1-q$ represents the yes/no categories, $z_{\alpha / 2}$ is CDF of normal distribution and finally $\varepsilon$ is the error term. Since we have $p=0.5, z_{\alpha / 2}=1.96, \varepsilon=0.033$ and $N=441782$, the number of sample size is calculated as $n=880$. Table 1 shows educational backgrounds of the participants.

\section{Table 1}

Distribution of the sample by educational level

\begin{tabular}{lcc}
\hline Educational level & Frequency & Percent \\
\hline Illiterate & 196 & 22.3 \\
Primary & 131 & 14.8 \\
Middle & 37 & 4.2 \\
Secondary & 313 & 35.6 \\
Graduate & 81 & 9.2 \\
Post-graduate & 96 & 10.9 \\
Ph D & 26 & 3.0 \\
\hline Total & 880 & 100.0
\end{tabular}

Education-wise, most of the sample belonged to secondary level of education (35.6\%), which is followed by illiterates (22.3\%). A glimpse at the table clearly reveals that we find less and less number of Iranian female respondents having higher levels of education. From graduation to Ph.D we find on the whole only about 3\%. Further, chi-square test revealed significant difference between different frequencies of educational levels. Table 2 demonstrates the nature of employment among people who tool part in our survey.

Table 2

Distribution of the sample by present occupation

\begin{tabular}{lll}
\hline Occupation & Frequency & Percent \\
\hline Business/industrialist & 10 & 1.1 \\
Salaried employment & 31 & 3.6 \\
Temporary govt job & 10 & 1.1 \\
Regular private sector job & 12 & 1.4 \\
Temporary private sector job & 8 & 0.9 \\
Petty trader shop keper & 7 & 0.8 \\
Self employed professional & 7 & 0.8 \\
Other & 3 & 0.3 \\
Not Applicable & 792 & 90.0 \\
\hline Total & 880 & 100.0 \\
\hline Chi-square=5550.29; $\mathrm{P}=.000$ & &
\end{tabular}

It was quite alarming fact that $90 \%$ of the Iranian women sample selected did not have any job. 3.6\% of them were on salaried employment, $1.4 \%$ of them were on regular private sector job, very few of them were in business/industrialists, few of them had temporary government jobs as well as temporary private jobs (Fig. 1). When all these frequencies were subjected to chi-square analysis, chi-square test revealed a significant difference among these frequencies; further confirming that majority of the selected sample did not have the job. 


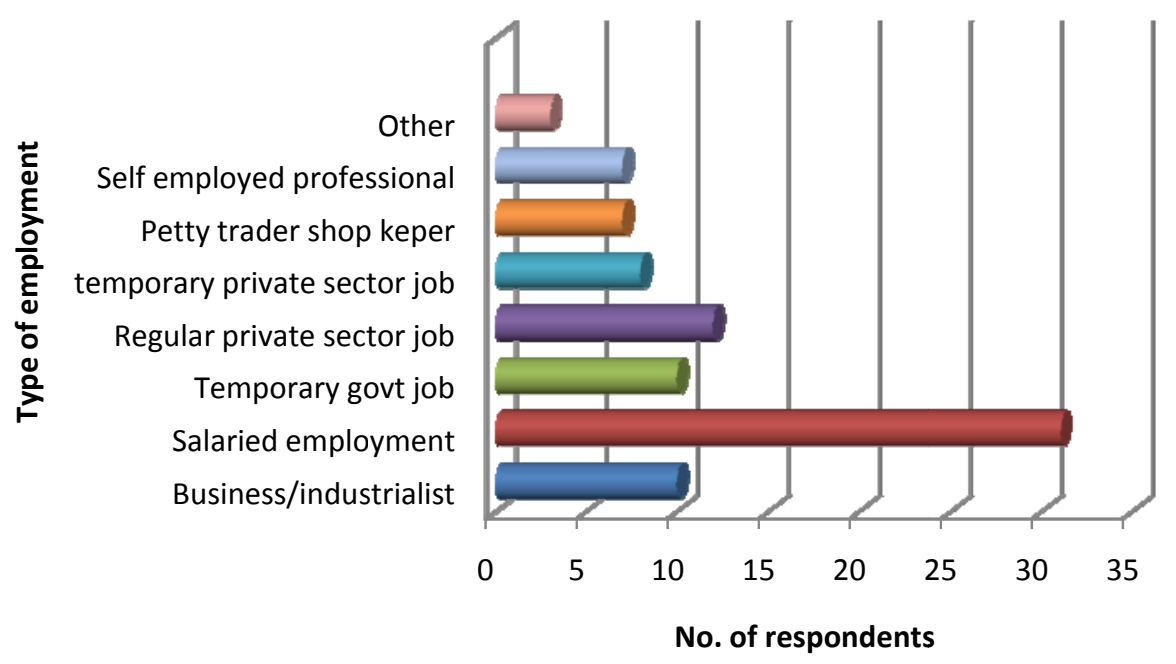

Fig. 1. Distribution of the sample by present occupation

Table 3

Association between educational level and Occupational level among Iranian women

\begin{tabular}{|c|c|c|c|c|c|c|c|c|c|}
\hline \multirow[b]{2}{*}{ Occupation } & & \multicolumn{7}{|c|}{ Education level } & \multirow[t]{2}{*}{ Total } \\
\hline & & Illiterate & Primary & Middle & Secondary & Graduate & Postgraduate & Ph D & \\
\hline \multirow{2}{*}{$\begin{array}{l}\text { Business/ } \\
\text { Industrialist }\end{array}$} & $\mathrm{F}$ & 0 & 0 & 0 & 0 & 10 & 0 & 0 & 10 \\
\hline & $\%$ & $.0 \%$ & $.0 \%$ & $.0 \%$ & $.0 \%$ & $12.3 \%$ & $.0 \%$ & $.0 \%$ & $1.1 \%$ \\
\hline \multirow[t]{2}{*}{ Salaried employment } & $\mathrm{F}$ & 0 & 0 & 0 & 3 & 0 & 28 & 0 & 31 \\
\hline & $\%$ & $.0 \%$ & $.0 \%$ & $.0 \%$ & $1.0 \%$ & $.0 \%$ & $29.2 \%$ & $.0 \%$ & $3.5 \%$ \\
\hline \multirow[t]{2}{*}{ Temporary govt job } & $\mathrm{F}$ & 0 & 0 & 0 & 10 & 0 & 0 & 0 & 10 \\
\hline & $\%$ & $.0 \%$ & $.0 \%$ & $.0 \%$ & $3.2 \%$ & $.0 \%$ & $.0 \%$ & $.0 \%$ & $1.1 \%$ \\
\hline \multirow{2}{*}{$\begin{array}{l}\text { Regular private } \\
\text { sector job }\end{array}$} & $\mathrm{F}$ & 2 & 0 & 0 & 6 & 2 & 0 & 2 & 12 \\
\hline & $\%$ & $1.0 \%$ & $.0 \%$ & $.0 \%$ & $1.9 \%$ & $2.5 \%$ & $.0 \%$ & $7.7 \%$ & $1.4 \%$ \\
\hline \multirow{2}{*}{$\begin{array}{l}\text { Temporary } \\
\text { sector job }\end{array}$} & $\mathrm{F}$ & 0 & 0 & 4 & 0 & 0 & 0 & 4 & 8 \\
\hline & $\%$ & $.0 \%$ & $.0 \%$ & $10.8 \%$ & $.0 \%$ & $.0 \%$ & $.0 \%$ & $15.4 \%$ & $.9 \%$ \\
\hline \multirow{2}{*}{$\begin{array}{l}\text { Petty trader shop } \\
\text { keeper }\end{array}$} & $\mathrm{F}$ & 0 & 7 & 0 & 0 & 0 & 0 & 0 & 7 \\
\hline & $\%$ & $.0 \%$ & $5.3 \%$ & $.0 \%$ & $.0 \%$ & $.0 \%$ & $.0 \%$ & $.0 \%$ & $.8 \%$ \\
\hline \multirow{2}{*}{$\begin{array}{l}\text { Self employed } \\
\text { professional }\end{array}$} & $\mathrm{F}$ & 0 & 6 & 0 & 1 & 0 & 0 & 0 & 7 \\
\hline & $\%$ & $.0 \%$ & $4.6 \%$ & $.0 \%$ & $.3 \%$ & $.0 \%$ & $.0 \%$ & $.0 \%$ & $.8 \%$ \\
\hline \multirow[t]{2}{*}{ Other } & $\mathrm{F}$ & 0 & 0 & 0 & 2 & 1 & 0 & 0 & 3 \\
\hline & $\%$ & $.0 \%$ & $.0 \%$ & $.0 \%$ & $.6 \%$ & $1.2 \%$ & $.0 \%$ & $.0 \%$ & $.3 \%$ \\
\hline \multirow[t]{2}{*}{ Not Applicable } & $\mathrm{F}$ & 194 & 118 & 33 & 291 & 68 & 68 & 20 & 792 \\
\hline & $\%$ & $99.0 \%$ & $90.1 \%$ & $89.2 \%$ & $93.0 \%$ & $84.0 \%$ & $70.8 \%$ & $76.9 \%$ & $90.0 \%$ \\
\hline \multirow[t]{2}{*}{ Total } & $\mathrm{F}$ & 196 & 131 & 37 & 313 & 81 & 96 & 26 & 880 \\
\hline & $\%$ & $100.0 \%$ & $100.0 \%$ & $100.0 \%$ & $100.0 \%$ & $100.0 \%$ & $100.0 \%$ & $100.0 \%$ & $100.0 \%$ \\
\hline
\end{tabular}

$\mathrm{CC}=.609 ; \mathrm{P}=.000$

A significant association was observed between education level of Iranian women with their occupational level as the obtained contingency coefficient of .609 was found to be significant at .000 level (Bishop et al., 1975, Christensen, 1997). From the table it is clear that most of the illiterates did not have jobs, most of the graduates were business/industrialists and most of the postgraduates were on salaried employment. Table 4 demonstrates the average incomes of the people who responded to our survey through questionnaire. 
Table 4

Distribution of the sample by monthly income (The income is in terms of million Rials)

\begin{tabular}{lcccccccc}
\hline Income & No income/job & Less than 1.5 & $1.5-3.0$ & $3.0-4.5$ & $4.5-6.0$ & $6.0-7.5$ & More than 7.5 & Total \\
\hline Frequency & 792 & 49 & 13 & 8 & 5 & 5 & 8 & 880 \\
Percent & 90.0 & 5.6 & 1.4 & 0.9 & 0.6 & 0.6 & 0.9 & 100 \\
\hline
\end{tabular}

Chi-square $=1042.24 ; \mathrm{P}=.000$

Income-wise analysis too revealed significant differences between frequencies of different income groups, where again majority of the sample did not have income as we find that $90 \%$ of the sample showed zero income. Of the remaining 88 sample, 49 of them were on the lower side of income ( less than 1.5 million Rials), 13 of them were in the income range of 1.5-3.0 million Rials, and very few of them had higher levels of income. Further, chi-square test revealed significant difference between these frequencies on different income levels. The other observation is the job experience the participants had in our survey. Table 5 shows details of their experience.

Table 5

Distribution of the sample by occupational experience in years

\begin{tabular}{lcccccccc}
\hline Experience & None & Less than 5 & $6-10$ & $11-15$ & $16-20$ & $21-25$ & More than 25 & Total \\
\hline Frequency & 792 & 14 & 40 & 21 & 5 & 5 & 3 & 880 \\
Percent & 90.0 & 1.6 & 4.5 & 2.4 & 0.6 & 0.6 & 0.3 & 100 \\
\hline Chi-square=687.98; $\mathrm{P}=.000$ & & & & & & &
\end{tabular}

Of the 88 Iranian female who had jobs, we find that 40 of them had 6-10 years of experience, followed by 21 of them had 11-15 years of experience, 14 of them had below 5 years of experience, 5 of them had 16-20 years of experience. Very few of them had above 25 years of experience. Further, chi-square test revealed a significant difference between different frequencies on number of years of service/experience.

\section{The results}

In this section, we present details of our survey, which are associated with the following hypothesis,

H1. Economically, Iranian women are placed well and job placement of the Iranian women is low.

H2. Educationally, Iranian women are quite forward and there will be definite reasons for drop out.

\subsection{The result for the first hypothesis}

Hypothesis 1 is accepted as we find that on the whole own house was found to be maximum (68.6\%), followed by orchards (48.5\%) and hose rented and leased were found to be least (16.8\%). 63.4\% of the sample possessed two wheelers, $61.0 \%$ of the sample had four wheelers and few of them had business establishments, share deposits and marriage gifts. Very few of them opined that they earned themselves orchards, barren land, house for own use, house rented and leased, shopping complex, cash received, and ornaments \& other valuables.

As far as the job placement is considered, from the tables it is evident that only $10 \%$ of the sample selected had either full time or part time employment. Hence hypothesis regarding job placement is accepted. An important activity of women in Iran is making handicrafts. Handicrafts a combination of art and technology which is mostly done by hand using local materials. Handicrafts require creativity, which Iranian women have, so their products are better than man-made products. According to published figures $70 \%$ of handicrafts in Iran are done solely by women. In the whole country there are 423,000 homes which are engaged in handicrafts. $88.7 \%$ of the special handicraft makers, such as weavers, are women. Only 11.3 are men. A large number of women are self - employed in handicrafts production. From economic point of view it needs only a minimal investment. In addition, women have time to do their housework as well. Women are interested in different handicrafts fond in their particular villages. In summary, the most important women's activities related to productivity are 
animal husbandry. Birds, bee-keeping and silkworms are also among the Iranian women's professions which bring economic benefits to the family. In general, different factors cause women to choose to make handicrafts, some of which are as follows:

a) Population growth decreases the number of jobs outside the home.

b) Girls learn their mother's art of manufacturing handicrafts at home so they start working.

c) Many women are artistically inclined and have more creativity than men.

d) Family need women's financial support.

\subsection{The result for the second hypothesis}

Almost $78 \%$ of the sample studied was literates. Only about $22 \%$ of them illiterates studied no formal education. Hence hypothesis 2 is accepted as we find that educationally women are quite forward as we find that the literacy rate is almost as same as national average (81\%) of Iran in literacy rate. The educational levels of Iranian women ranged from lower primary levels to highest degree of $\mathrm{Ph} . \mathrm{D}$. As far as the dropout reasons were analysed, it was found that there were definite reasons for drop outs as we find that $24 \%$ of total drop out from selection and of the specific reasons quoted more by the respondents were marriage, followed by financial problem and even attaining puberty was one of the major reasons for drop out. Hence, hypothesis 2 concerning that there will be definite reasons for drop out is accepted.

A few examples of the change that women have brought in their status over the past two decades. Existing figures about candidates of state university admission examinations show that the share of women in the total number of those sitting for the exams increased from 30.21 per cent in 1991 to about 52.1 per cent in 1998. At the same time, girls have been more successful in gaining entrance. For instance, in the current academic year, 51.4 per cent of candidates were women, of whom 52.1 per cent passed the examinations.

Although, in years between 1976 and 1986, the number of educated women increased and from $35.5 \%$ educated women in 1976 reached to $52.1 \%$ in 1986 , but on the one hand, the level of educated men is still in a lower position and on the other hand, in 1986, the number of the rustic women who were educated was at the lowest level (36\%). Despite of an increase in the level of education in the mentioned period, the number of educated women in urban areas has been more than rural areas in 1976 that was because of the emigration of villagers to the cities and not because of the lack of equipment for education in villages. On the other part, the increase in the number of educated people has been more in those less than 15 year old ones and the rate of education in adulthood has had a little increase. Considering the effect of higher education for women on decreasing birth rates, one must prepare the situation for them to continue their learning and be efficient in the country $\mathrm{s}$ economic expansion.

Women's education and their tendency to work is directly related and based on the educational properties and professional training that men and women receive. Although, duplicity in terms of economical activities can determine the relationship between women' s education and their economic participation, but one must be careful and do a lot of subtle study to be sure of it. Moreover, by preparing educational properties and professional training, one can expect women participation in economical activities will increase and a positive relation between education level and women participation will be established. The more we prepare women on educational and professional training, the more easily do they get jobs with better salary and fringe benefits. Women education, however, have some indirect but positive effects on their economic affairs and employment. It also, increases our expectations and decreases the influences of old customs. It also, prevents women from having many children and encourages them to marry late and postpone their pregnancy. All these 
transformations facilitate women's entry in to labour market. The main issue is that the girls are encouraged to get a job after graduating. Researches in developed countries show that if girls do not enter labour market after graduating, it is very hard to encourage them to enter to the labour market later.

There are few employment opportunities for women. According the Iranian Education Minister Hossein Mozaffar, the employment rate for women was nine percent and 72 percent of that was in the education sector.According to the President Khatami's advisor on women's issues, there are only three women among very 10,000 senior managers - the rest are men. An international study comparing workforce conditions for women around the world ranked Iran 108th out of 110. In urban areas women make-up only 9.5 percent of the workforce, and in rural areas the percent is 8.8 percent. Even Khatami's advisor on women's affairs acknowledged that there is discrimination in employment and promotion against women in government offices: "Some officials are of the opinion that men have more of a role in running the family, so they favor the men.”

\section{Conclusion}

In this paper, we have presented a comprehensive survey to investigate women's position in terms of two aspects of economic and education for the people who live in a city of Esfahan, Iran. We have designed a questionnaire and distributed among 880 people who were randomly chosen from a population of 441782 residence. The result of our survey confirms that Iranian women are placed well and job placement of the Iranian women is low. The second part of our survey has concluded that Iranian women were quite forward and there would be definite reasons for drop out.

\section{Acknowledgment}

The author would like to thank Islamic Azad University for their financial support on this project. The author also grateful for constructive comments received from the anonymous referees on earlier version of this working paper.

\section{References}

Bishop, Y. M. M., Fienberg, S. E., \& Holland, P. W. (1975). Discrete Multivariate Analysis: Theory and Practice. MIT Press.

Boschmann, E.E. (2011). Job access, location decision, and the working poor: A qualitative study in the Columbus, Ohio metropolitan area. Geoforum, 42(6), 671-682.

Burrell, J., Manfredi, S., Rollin, H., Price, L., \& Stead, L. (1997). Equal opportunities for women employees in the hospitality industry: a comparison between France, Italy, Spain and the UK. International Journal of Hospitality Management, 16(2), 161-179.

Chi, C.F. (1999). A study on job placement for handicapped workers using job analysis data. International Journal of Industrial Ergonomics, 24(3), 337-351.

Christensen, R. (1997). Log-linear models and logistic regression. Springer Texts in Statistics (Second ed.). New York: Springer-Verlag.

Kriesi, I., Buchmann, M., Sacchi, S. (2010). Variation in job opportunities for men and women in the Swiss labor market 1962-1989. Research in Social Stratification and Mobility, 28(3), 309-323.

Hurd, M., \& Panis, C. (2006). The choice to cash out pension rights at job change or retirement. Journal of Public Economics, 90(12), 2213-2227.

Pfister, G., \& Radtke, S. (2006). Dropping out: Why male and female leaders in German sports federations break off their careers. Sport Management Review, 9(2), 111-139.

Raymo, J.M., \& Lim, S.-J. (2011). A new look at married women’s labor force transitions in Japan. Social Science Research, 40(2), 460-472.

Sabharwal, M. (2011). Job satisfaction patterns of scientists and engineers by status of birth. Research Policy, 40(6), 853-863. 
Wild, R. (1970). Job needs, job satisfaction, and job behavior of women manual workers. Journal of Applied Psychology, 54(2), 157-162.

Winterhager, H., Heinze, A., \& Spermann, A. (2006). Deregulating job placement in Europe: A microeconometric evaluation of an innovative voucher scheme in Germany. Labour Economics, 13(4), 505-517. 